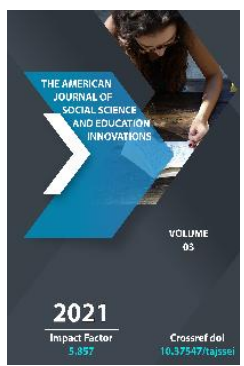

\title{
Mahmudkhuja Behbudiy - The Symbol Of History
}

\author{
Abdulla Ulugov \\ Associate Professor, Candidate Of Philological Sciences, Tashkent State University Of Uzbek \\ Language And Literature Named After Alisher Navoi, Uzbekistan
}

Journal Website: http://usajournalshub.c om/index,php/tajssei

Copyright: Original content from this work may be used under the terms of the creative commons attributes 4.0 licence.

\section{ABSTRACT}

Mahmudkhuja Behbudiy holds a special place in the history of the Uzbek people as a person who devoted his life to the prosperity of the country. The history of the Uzbek people of the 20th century can not be imagined without its vibrant socio-political, literary and educational activities. He actively participated in the socio-political movements of the period, gained fame as a political figure, selfsacrificing educator, co-founder of the new Uzbek literature, founder of the new school, theater, publisher, newspaper, organizer of magazines, was one of the first to raise the socio-political, spiritual and educational problems of the time in his literary and artistic works. In this article, Mahmudkhuja Behbudy's "Padarkush" drama and some articles on the social importance of the comments were made.

\section{KEYWORDS}

Mahmudkhuja Behbudiy, national life, colonization, enlightenment, ignorance, science, "Padarkush" drama, article, Islamic religion, development.

\section{INTRODUCTION}

Mahmudkhuja Behbudiy (1875-1919) is one of the great figures who started to update in Uzbek literature. Long centuries in Uzbek literaturewith his activity, he encouraged his compatriots to change the existing social situation, to take up the achievements of 
modern science and to raise them to the level of advanced countries. The ideas he put forward later became the foundation for the changes that occurred in social life. Mahmudkhuja Behbudy, who wrote in 1911, "Padarkush" was recognized not only as the first drama in Uzbek, but also in the literature of the peoples of Central Asia. "This drama is a work that has launched a new Uzbek literature" (Behbudiy M. Selected works. Tashkent: "Spirituality", 1997. - 232 p. - 11-page). The drama "Padarkush" had an effective impact on the new Uzbek literature. Founder of the Uzbek novel chunanchi Abdulla Qadiri said: "I could not notice myself writing the book of the theater "the unhappy groom" under the influence of Padarkush, which came out in 1913 "(Kadiri A. Small works. - Tashkent: publishing house of artistic Literature named after Gafur Gulom, 1969. - 216 p. - 206page).Mahmudkhuja Behbudiy was one of the first to raise the actual problems of his time. His "Padarkush" drama, many socio-political problems, which were revealed in his articles, later attracted the attention of other creators. Because the author of "Padarkush" was one of the most progressive-minded people of his time. In this regard, Fayzulla Khujaev said: I do not think that in terms of the breadth of political, social activity and knowledge, one of the jadids of Turkistan at that time is equivalent to Mahmudkhuja Behbudiy (Behbudiy $M$. Selected works. - Tashkent: "Spirituality", 1997. - 232 p. -5-page).And Fayzulla Khujaev (18961938) is a state and political figure, he was born in Bukhara in the family of a large merchant of his time. He studied at the madrasa in Bukhara, studied at a private school in Moscow in 1907 1912 years. From 1912 he was a member of the party "young Bukhara", from 1913 he was a member of the party Central Office. The great wealth Inherited from his father was spent on opening new method schools, material support for the political activities of the "young Bukharian". From 1917 year Fayzulla Khujaev and Fitrat headed the macro wing of the party and fought for the establishment of a constitutional monarchy and then a Democratic Republic in Bukhara. After Fayzulla Khujaev and his comrades were forced to leave Bukhara, which was followed by the" young bukharians.

Mahmudkhuja Behbudiy, Abdurauf Fitrat, Sadriddin Ayni, the descendant of the steppes lived in this period full of dignity and saw with his own eyes all the informality and injustices that the human values in it. The fact that ignorance caused by disgrace in social life, injustice reigned in life, humiliation of a person, ignorance born due to lack of Enlightenment made people a spiritual disorder caused them to suffer in vain. And Allah has shown to his servants that he is very kind and merciful even in this historical time. That is, "in the shadow of the fact that God does not wrong the truth" (Qadiri A. Past days: historical novel. Tashkent: publishing house of literature and art, 1974. - 400 p. - 233 page) who took the field of self-sacrifice, who defended the interests of the oppressed, who took the side of the despised, insulted, who fought to change the social stand based on oppression and tyranny. It is interesting that in life, the truth is that all the leaders, leaders of those who fought for justice to be stable, the leader was not from among the oppressed poor poor, but from within the upper strata of the population. For example, the father of Mahmudkhu'jaBehbudi was Imam Khatib and his uncle was Mohammed SiddiqQazi. He himself studied at the Samarkand and Bukhara madrasasahs, began mirzolik in the kazikhan from the age of 18 and was promoted to the rank of Qazi, mufti 
(Behbudiy M. Selected works. - Tashkent: "Spirituality", 1997. - 232 p. - 7-page). AbduraufFitrat's father, Abdurahimboy, was one of the intellectual rich of his time. Her mother Mustafbibi (in the family she was called Bibijan) was an educated woman, and the education of her children also had to be engaged in her upbringing alone... AbduraufFitrat first studied at the elementary school, then at the Mirarab madrasah in Bukhara, at the prestigious dorilfunun in Istanbul in Turkey, at the gymnasium of teachers, at the Weizin Madrasah" (Fitrat A. Selected works. Volume 1: poems, prose works, dramas. - Tashkent: "Spirituality", 2000. - 256 p. - 5-7-page). As for the biography of the steppe: "son of Abdulhamid Suleiman was born in 1898 year in the family of Solomon bazzoz, who was engaged in the sale of gaskets in Andijan. His father was engaged in commercial affairs at the latitude from Andijan to Orenburg, he was a merchant of the level of such famous rich people as the city's Mirkomilboy, Ahmadbek Haji, Kipchakboy" (the Steppe. Works: four volumes. Volume 1: poems, cults, poetic letters. - Tashkent: "Akademnashr", 2013. - 384p.- 5page). All of them devoted their lives to the transformation of the existing social situation, which has become dark since the fall into the swamp of darkness, ignorance, obscurity, the improvement of people's lives, the liberation of the country from the grip of colonialists, the struggle for the achievement of the free and free life of their compatriots. Mahmudkhu'ja Behbudiy and his followers have left traces in history such as Folk, patriotism. Because of their multifaceted activities, such as political, scientific-pedagogical, publishing, passionate and burning literature, they had an effective influence on the awakening of the national consciousness of the Uzbek people, the formation of the spirituality of their compatriots, their worldview. They lived in a very difficult and difficult time - the colonial policy prevailed in the world, a social crisis occurred in the country, people's minds were poisoned by ignorance, the vice of fanaticism, the practice of career strife, bribery, repression, mutual conflict, conflict, scandal, violence, and were engaged in extensive activities.

Mahmudkhaja Behbudiy and his selfless comrades were supported by history himself as a courageous, courageous and tolerant fighter, putting him on the field "in the shadow of the fact that God does not wrong the truth." Therefore, despite the fact that they have a lot of different obstacles, they have encouraged people to abandon ignorance, to master enlightenment, to introduce the achievements of modern science into marriage. To this end, they raised the idea of creating schools that teach their children in a new way, opened such a school themselves, prepared educational programs for these schools, wrote manuals, textbooks, published complexes and gave lessons to children. As a result of these works, it was difficult for a person to perform, he showed enthusiasm as a poet, writer, playwright, organizer of theater, troupe, director, actor, composer, printing house, gazeta, magazine founder, publisher, journalist. Those who devote their lives to the struggle for freedom and freedom, truth and Justice, have encyclopedic knowledge, operate on a wide scale, begin to enlighten and develop people with their multifaceted creative search, inspire in their hearts humanism, patriotic feelings kuchaytirib, and noble deeds, and the manifestations are not always, but not always, every time-comes to the world when historical necessity arises. They believe that people come to the field as a savior when they are spiritually 
oppressed and persecuted to each other and awaken the people from their misery, that their lives are living in suffering, that such a life can not be lived. And people always follow their call, taking power from the words of the deliverers, warning them of the original truth. Because these rescuers, who have made history, appear as advanced-minded people of our time and become an example of a lesson for others with their personal lives, intense social activities. They attract the attention of everyone, as they prefer the interests of el-yurt over his own enjoyment. The biography of mahmudkhajaBehbudy indicates that he was such a selfless person that he created a historical necessity. His whole activity, the drama "Padarkush", his articles are imbued with the spirit of patriotism, can serve as the basis for such a conclusion. In particular, it is noted that the drama" Padarkush " had an effective impact on social life, the literary process, those who watched this work on the stage went out of the theater with tears, and the penkashs imitated it and wrote a number of works. MahmudkhajaBehbudiy did not neglect the sad situation of the people of Turkestan, who were ignorant as a result of innocence from enlightenment. He, as a progressive person of his time, came out of the current situation and showed the way to correct the situation. In order to get rid of the backwardness and achieve the standard of living in the advanced countries of the modern world, it is necessary to grow the consciousness of people and expand their worldview, for this it is necessary to enjoy their enlightenment. MahmudkhujaBehbudiy and his comrades reformed the education system for the peoples of Turkestan, which remained in the colonial grip, realizing that opening new schools, retreating from the traditions that reigned in the literature of long centuries, updating it in terms of form and content, reflecting the reality of life in the works is a matter of life and death. The three foundations - based on a new school, literature and theater, aimed at raising people's minds, enriching people's worldview and reforming social standing on this basis. Therefore, their personal life and social activities are directly connected with school-education, literature and theater. Among these three bases, literature occupies a central place. Because both the educational system and the theatrical art are fed from literature. Through his intense activity as a writer, playwright, journalist, publicist, publisher, Mahmudkhuja Behbudiy proved that it is possible to change the consciousness and outlook of people in the media of literature and on this basis to reform social life. His "Padarkush" drama was staged in janvar in 1914 year 15, when "the people came a lot, did not belat and went back three or four hundred people for lack of space, the personages in the drama-domla and the advice of the intelligentsia affected the crowd, and there were also those who cried to WA'zuPand, the spectacle was studied Russian, Jews and Muslims, it is noted that the building of the Ebrat House - Theater was humped" (behbudiy M. Selected works. Tashkent: "Spirituality", 1997. - 232 p. -11-12page). Famous enlightener abdullaavlani's troupe "Turon" began its activity with the performance of the drama "Padarkush" on the stage, before the performance of the play the speaker made a speech about the role and role of the theater in the life of society at the present time, this date, which was shown in Tashkent, was described as "historical day" in the local mutbuat as it arises from the deep sense of the socio-political, culturaleducational need of the modern. 
The pand-instruction of mahmudkhu'jaBehbudy, which is permeated with the spirit of humanism, is based on the Qur'an verses of the word of Allah and the hadiths of our Prophet Muhammad alayhisalom. He presents his thoughts on the current situation in the world and the deplorable situation in our social, spiritual and moral life through examples from the life story. Mahmudkhaja Behbudiy analyzes the main content of his works, articles, life events. The article "us rodent vices" can prove this. In order to attract attention initially in the article "do you suspect zakhmumaraznimi when we say rodent vices? What do you say about erariyau?"the question is put and is answered "No, it is not". We see that the vices that rodent Turkestan are worse than zakhmuMaraz and Silva sil AR riyau. This vice is called "the wedding and the enemy of the two rushes in the name of azo", and he is called" the crisis and danger and hell will roll over US." Through such bitter and truthful words in mahmudkhajaBehbudiy's articles, the new era opened the way to realistically reflect the reality of national life in Uzbek literature. He warned the people of Turkestan that it is impossible to live in such a deplorable situation, which is behind the development of the times in the colonial settlement. The author of" Padarkush " believes that it is ignorance to remain innocent from enlightenment, not to master the achievements of modern science, that an ignorant person can become a murderer of his father if he does not want or does not want to. In his article "the ills that bite us", the wedding and the event related to mourning, the ceremonies have proved to everyone in an understandable way how much grief and concern they bring to the Turkestan. In his article" a'molimizyoinkimurodimiz", he continued his comments on this issue again. In both of his articles, the author noted that the turkistanites did not pay attention to the fact that they are free and not free as human beings, the reason for the negligence of the mastamlakacists in finding the native land is that the consciousness of the local population has become immeasurable, they have spent all their strength and time on weddings and mourning To do this, initially focusing on what is the main purpose of our people in life :" most of our people are a'Imolişulki, if worklasa and profit. Maybe the boy and his daughter have a wedding and how! More than the wedding that made people in their row! Poor kosibnia'moli wedding is poor. He himself does not see the face of pleasure. Night and day 18, maybe 20 hours of Labor, we have the kosibler. The truth is not to eat, not to wear. Ten and twenty dates to Labor and toil and beg the son of God, to have a wedding. Those poor man a'moli. Twenty-date labor three days are complete at the wedding. Yana Ahmadiporina (suprindi, go'o), towels and room girad. Avoid debt holders for wedding pluses (expenses). Having a large wedding, the wife should cry a piece of olgon the poor souls. The three-day wedding matinee lasts a decade or even a lifetime in some families, but also causes impoverishment and ruin " (that source. -156page).Mahmudkhu'jaBehbudiy showed that he lived with his kindness and grief of the nation both in the"vices that rodent us "and in the"A'molimizyoinkimurodimiz" and in other articles. He described the grief of the hardworking people who, both in the drama" Padarkush", and in the"memories of travel", and in the"appeal to respectable young people" ida, singled out from the plight of their nationalities, spouses, fight for Truth, Justice. He went to foreign countries, he saw how people live in those places and compared the life he witnessed with the turkistans ' prison :" 
O people! O Muslims! We do not speak of God, The Messenger, for na and follow ourselves nafimizga? Are we Devan?"he cried out. The reason for his suffering is this: "do not throw yourself to the rescue with your own hands, that is, in the"Holy Quran "of our merciful Lord Jello," Lo talaqqoboyadikumala danger". When we are unhappy,ettetera and blasphemous without putting the vision of the commandment of God that says wedding and mourning in a photo, we are spending and wasting our lives on the habits that cause our extinction" (that source. -145-page). After that, these comments: "in two months Navrettirmiz travel to kofiri. A month ago,only three people died and more than ten were injured from the shooting of fireworks on the same trip to the Samarkand region of Panjakentqasab. Kubkari and Capricorn the habit of strabismus from every province of Mal'unasig, with every sanayuz people have moved to the hereafter, nor have people been injured and Ma'ub. Many people travel and remain from work and farming time to time with the plow of many. For $\mathrm{Na}$ who would take a horse for quite a few hundred rubles and spend a sum every day on reaching (ixlos, intensely) adore anga turkeys every day? Wedding and sightseeing to chop off the frock. Ten or twenty paces before the wedding, everyone would put his work, his peasant, jump and leave for many. From gold to the peasant became a dear zamanvaft-gone. The crop remains uncooked for sprinkled only after a day. The only day left in the rain to be collected afterwards, some thresholds would rot, " he said, citing them through the wall.MahmudkhujaBehbudiy wrote "Padarkush", "us rodent vices", "our A'molimizyinkimuradimiz" and other works because he could not tolerate the suffering of his kindness and love for his compatriots, his wives, his sympathy for his sober
condition.Because in his works the soul of the Impressionist is a reflection, the argument of the person who thinks, observes is a bubble.From the works of mahmudkhu'jaBehbudiy and his comrades, the heart cries of the dashing man are heard. These zeros are chuchmal, not sentimental. Their suffering grows from the miserable situation of the turkistans, who are behind the development of modern times due to the fact that their four lives are in their own, colonial residence.

- Mahmudkhu'jaBehbudiy drew attention to the fact that the local population has moved away from Enlightenment, has been given superstition, has been suffering himself without following the Islamic religious procedures: "in a city known, Jews sometimes bury their dead in the evening. For $\mathrm{Na}$ ? They stay out of work during the day. If we are dead, and for the wedding, weeks, even months, we are left from work. Nevertheless, shore'iA'zam, the prophet muhammadsallollohu bless those who die quickly buried he then quickly dissolve and jamesko'mvasallamhazratlariAkram, occupation and condolences from people ketmoqg'ao'lukxona increases tutmasg'a three days, the servant kiymasg'a,laundry, disaster bo'Imasg'a command to do so:" that was sing (those source. - 145-bet). MahmudkhajaBehbudiy and his comrades aimed to awaken the local population from ignorance, to open the eyes of their nationalists by criticizing the widely-rooted vices in marriage.The same feature is shown in the drama"Padarkush", in which the son becomes a murderer of his own father, by joining the bully, " a shopkeeper, a florist, a fortuneteller,for a kosib these weddings and Obituaries contribute from death, for muning 
the poor die every day." Every day the Dead will not be saved though.From himself then Ahlulqadinig'a this poverty, and he will inherit this calamity " (that source. - 147-page) will show in the so-called. The death of the father in the drama" Padarkush "by itself" Who and why killed him?"that raises the question.The comments of mahmudkhu'jaBehbudiy and his comrades about the wedding and the problems with mourning, which he expressed with sympathy, make people think about the fact that they are left in ignorance. The author of the" vices that gnaw at US "gives a glimpse of the nationalities, their wives, who remained unaware of the death of the father in the drama" Padarkush". Because from the first drama in the new Uzbek literature, the author's articles such as "a'molimizyoinkimuradimiz", "appeal to distinguished youth", "vices that bite us", the distance from Enlightenment, the nonobservance of the Islamic Shariat leads the people of Turkistan to tragedy. MahmudkhaBehbudiy, AbduraufFitrat, Steppe, without being a representative of the upper class, take the side of ordinary people, protect the interests of those who suffer from ignorance, read in their schools, education,to be honest, burn the soul for education, all ajablantiradi. Because a person's own people, his class, his own stratagem, going to the contrary, is not considered an acceptable work in a given time. The man who wrote "the vices that bite us" and his comrades, and the followers know very well what is acceptable, what is not acceptable. MahmudkhaBehbudiy, despite his belonging to the upper stratum of society, thinks and meditate on the Nafs of ordinary people, and not rulers, officials. He does not keep secret his thoughts about the fact that the local population has become a spiritual disorder due to the infallibility of enlightenment, that people practically fail the Islamic Shari'a, that superstition is widespread in life, what they hate and what they suffer, he says it all openly. Therefore, the respect of advanced-minded people to Mahmudkhu'jaBehbudiy was high. When the author of the" vices that gnawed US "expressed his views on the national life stories, when his nationalists thought that he had forgotten the religion of Islam, he took an impartial approach to the problem and strengthened his thoughts through the hadiths of the Prophet (SaaS), starting from the justification of the verses of the Qur'an. For example, in the" vices gnawing at us":"the danger of Lo talaqquoboyadikumala in the"excellent Qur'an "of our kind God Jello from our Atom," say "do not risk yourself in your own way (that source. During the same article, he wrote:" whereas, a member of shore, the Prophet AkramSallAllahu Al-khazrat, would command the people of the dead to not wear mourning, to not wear mourning,to not be a disaster, to not bow down and to the people of the dead for three days, to spread quickly after burial, and not to bow down." So, he acted as a perfect Muslim,who liked the truth, justice, even in his literary works, articles, social activities. However, the majority of officials, especially the qazi and muftidis, in all times carried out activities aimed at their wellbeing, thus adapting the Shari'ahtraditions. They served for the benefit of the ruling class, and not for the realization of justice, for the restoration of truth. And mahmudkhu'jaBehbudiy, unlike them, was eager for the benefit of el-yurt to be bright and to be free from the whirlpool of colonialism and backwardness,taking advantage of the Enlightenment rays of the wives and compatriots. Therefore, he was recognized as one of the largest figures of socio-political 
movements in his life, under the leadership of the Turkestan jadids, the founder of the new Uzbek culture.Because he fought against enlightenment,ignorance, injustice, oppression and violence,likeDidro, Russo, Montesque, Gyote, Tagor, and showed his way to victory over ignorance in his drama "padarkush or the holiness of an uneducated child", "the story of a Chinese woman with a white elpogger", "travel memories", articles, textbooks.His writing is an unprecedented triumph of ignorance, forced to think about the sad consequences of it,we must strive to fight back the traditions, strive for enlightenment, study science, master modern techniques and live a comfortable life. The drama "Padarkush" is the main work of MahmudkhujaBehbudy. He is also the first drama in the new Uzbek literature. The struggle against enlightenment, ignorance determines the meaning and essence of this drama. The author shows in it that neglecting the work of Education, moving away from scientific enlightenment to their wives,nationalists, all people,makes people spiritually ignorant and ignorant. Therefore, "Padarkush" is recognized as a work of both literary and socio-educational significance. In the events of the plot of this drama stands the image of the author, who calls to fight against ignorance in the center of the work,although the boy is rich, his son Tashmurod, domullo, an educated, mirzasikhayrullo, a Tangrikul who killed the boy, his partners are the state and Boz children named Nor,a Russian wife of a qabiha named Liza, an ArmenianThe author shows the deplorable consequence of spiritual debauchery by demonstrating the actions of people who remain in ignorance.Drama educated: "the end of Science and illiterate children(ng) is shul. If only the father had taught these things, it would not have been a crime and a padercushlik, and these would not have made the diet indifferent right, without drinking alcohol alone. He would not have remained in hell for as long as his life and for the band and the doomsday. If these were not to drink, the world and the hereafter would not have suffered and labored forever. Oh, in truth, it is the illusion that he killed the rich and made the suffering of the young man forever " (Behbudiy M. Selected works. - Tashkent: "Spirituality", 1997. - 232 p. - 49-page). In fact, these words were a call that these books sought through the works of MahmudkhaBehbudiy and his comrades, followers, all his life. The author of" Padarkush " encouraged everyone to draw the necessary conclusions from the tragedy of the father,who was indifferent to the teaching, education and upbringing of his child, and from the state of an uneducated child, by making the national life story clear to everyone in a simple and simple way. The drama" Padarkush or the state of an uneducated child " gave an impetus to the emergence of many works put forward in the new Uzbek literature. They had an effective influence on the literature of the Kazakh, Kyrgyz, Turkmen, Tajik peoples, and also appeared in them works of the same direction.Because the rich in the drama "Padarkush", and his son-a typical embodiment of those who looked indifferent to enlightenment.The game shows the reasons for the demise of the Turkestan country, which remained in the colonial grip and was immersed in superstition and heresy. In the same work of mahmudkhajaBehbudy, a vivid expression of the crisis of Turkistan, the colonial countries was made. "Padarkush" at the same time, its author shows that he lives with grief for the benefit of the nation, his compatriots have gone away from enlightenment and suffered in vain for being given superstition. This drama "description 
case", "appeal to distinguished youth", "teyotrnadur?"Articles such as "a'molimizyoinkimurodimiz", "not two but four languages are necessary" show that the author's worldview is very broad, his knowledge is profound, he feels the life-giving power of knowledge and life-long boiling life, he is by nature influential,FayzullaKhujaev says about him that " in terms of the breadth of political, social activity and knowledge, I think.The literary heritage of Mahmudkhu'jaBehbudy "can be a clear proof of the fact that from the works of geniuses one can get a lot of information about their childhood, dreams, interests, aspirations, behavior, nature, troubles, in general, about life and about the time when they lived. Because he himself saw and spoke about the fact of life on the basis of the events he witnessed. In" Padarkush "MahmudkhaBehbudy manifests himself in the name of domulla and intellectuals, in his articles he reacts to life events, problems in him as a progressive enlightened person. Attitude to enlightenment esahar not only shows the human image of a person, but also determines the general landscape of society, the way of life of the people in it. The rise and decline of society is directly dependent on how much respect is given to the foundation of the attitude to science. Where the right of man is found, in a country where justice, law is not a priority, people can not live freely and freely. This in itself causes various conflicts, conflicts. An example of the situation in Turkistan shows the landscape of degradation in the colonial countries. MahmudkhajaBehbudy in the drama" Padarkush","travel memories", in his articles in the Press, revealed the causes of the crisis. Literature, theater and school were the areas of self-expression for MahmudkhaBehbudiy and his comrades. They gave up their enjoyment and suffered from the sad situation of their compatriots and nationalities, as it was possible to live a full and comfortable life in all respects. MahmudkhujaBehbudiy achieved the honor of" rahnamosi of the jadids of Turkistan"," dohiyiTuran"," ustodioliyshan " with his works of kindness to his nationalities, wives, who loved the truth,justice, intense social activity. On the example of the situation in the same family in the drama" Padarkush " he revealed that the people of Turkestan are immersed in superstition as a result of moving away from enlightenment, forgetting the Islamic Sharia. He tried very hard to convey this work to the oppressed nationalists. It was not easy to make Padarkush available to the public.This was written in 1911. Because of this writing, if necessary, the Tbilisi censorship allowed the release of the drama (Behbudy $M$. Selected works. - Tashkent: "Spirituality", 1997. - 232 p. 10-page). This trick in the emergence of the drama" Padarkush " is also evidence of the extreme kindness of God to all his servants, the realization of the truth, of course.Because there is no connection to the plot of the "Padarkush" of the war between Russia and France in 1812 year. It turns out that the fate of the drama" Padarkush", surpassing its various obstacles and becoming famous, is that any work is actually a test for people, each change takes place in the shadow of the fact that God does not wrong the truth. The drama shows that through the images of domulla and intellectuals, science-enlightened people miss good deeds to their compatriots, nationalists, lead people to the right path. In the image of rich people, esamol is proud of the wealth of some people who have placed an ambition in the world and it is noted that they look at the people of Science with indifference and act in the opposite way to their sons and friends. 
Domulla:" the reason for the debt and knowledge to readiszatidunyo and thanks to the hereafter "rich:" manihayalımğa (I thinkA.He), the cause of the world, the might wealth. If to the hereafter, the fate that God has made will be. Indeed, we see that people try to make the rich more self-esteem than the mullah" (the same source.- 40-page).Domulla: "the glory of the rich is temporary and the eyes of the people are open.Whereas, Alari(the rich - A.He if mullani is, then all the people are respected, that is, the knowledge of mullani is respected... The knowledge and necessity of Sharia is spoiled for knowing the world (Boy's son Tashmurod-A.If he tries to understand his own opinion that" you really need to read $(\mathrm{He})$, "the rich says to him:" I do not need to teach Sharia science. Because I am not going to ANI mufti either Imam and muezzin...Mani illiterate, bovujud, I am one of the great Richs of this city and I know every job." On the basis of the boy's dialogue with the domulla and the intelligentsia in the" Padarkushda", the chapters on the transformation of Turkistan into a colony are opened. On the example of domulla and ziyoligabepisand treatment of the rich, their denial of the word, it is shown that the rich and the officials of the country morally went bankrupt, many of them put without exaggeration Sharia. Currently, the focus is also on the works of Abdulla Qadiri,the steppe, the Fitrat. These are all people who are capable of what they say, Let Them Be Evil from the separatism, let them be conscientious, they do not have the right to beg. Kalender, Meddah...gambling agchas, which are found as if there are big big rich inside our named safillarımızın(pastkash, tuban), the Breakers of cannabis also do not make themselves, shape, young, children of mist are also victims of this bad profession.To these unfortunate: quot; yourself-yourself,now it will not be good if you teach your son a profession?"pattern :" o-y, this profession is the future work that is left from our ancestors. Everyone should earn their father's profession!", shall answer. You will see! Begging for alarming is a craft father's legacy in itself! Today's social scientists are seriously opposed to Islam as it is against such gross tobacco consumption. "It is better to buy from the mountain grass and give alms to those who need it than to beg and walk," Hadiths are called from begging and begging the people (Qadiri A. Country Bumpkin: poems, stories, stage works, hangoma, fel'eton and articles. - Tashkent: "new generation of the century", 2007. - 472 p. - 67 - 68-page). MahmudkhaBehbudiy and Abdulla Qadiri from the excerpts from the articles" vices that bite us"," appeal to distinguished young people"," a'molimizyoinkimurodimiz "or" begging or light profession " seem to penalize the illusions in social life. But in fact, they write in these articles their own experiences, sufferings. Because it is clear that both the author and the protagonist of these articles are their own. The authors of "Padarkush" and "past days" consider in their articles in everyday life, calling people to noble deeds, creative works, abandoning ignorance during the reporting of witnessed events and the thoughts born under their influence. Therefore, the artistic works and articles of Mahmudkhu'jaBehbudiy and his comrades are considered as a special reflection of the life of Turkestan of that period, the most magnificent examples of new Uzbek literature. Many ideas, problems that they raised, not only at that time, but also today have not lost its relevance. ChunanchiMahmudkhaBehbudiy wedding and mourning-related ritual, which has shown us as "rodent vices", the rituals also cause our compatriots a lot of anxiety, suffering at the present time. The wedding does not yield as expected measures aimed at 
regulating mourning ceremonies. Our compatriots still do not follow the rules of the Islamic Sharia and the procedures established by law on this issue. "The comments on the articles "vices that bite us", "the noble man yinkimurodimiz" always call for sympathy against superstitions, heresy, not allowing them in marriage. If the social and creative activity of mahmudkhu'jaBehbudi's comrades, such as Abdulla Qadiri, Chulpon,Fitrat, Hamza, is compared, then only very similar aspects are evident. This similarity is first clearly felt in the choice of a topic for their work, their approach to the problem and the interpretation of events. "At this time in the city there are big weddings, gamblers, drunkards stabbed each other, human blood "ignorance!!ignorance!!!"that was flowing...It's money from gamblers at a place a scramble. After Haji Ahmad came and preached and began to say, someone came and strangled Haji Ahmad and wounded Muhammad... Two sons of the Muslim rich of the city died playing cards drunk in the theater garden, while a little money was robbed, one pulled out his pistol and sent a shot at the other. Even if they caught the shooter and sent the wounded to the hospital, the wounded gave a soul on the road. The shooter was also surprised at this in the kindergarten and shot himself... Landscapes of beauty-far-far, great-great, green-green and high-high mountains were not inferior to the Swedeychara. The waters of the Nahr-nahr were flowing and the axis of what it could take, with fertile soil, there was nothing less than Amrica. With his wealth without knowledge, ignorant "scientists", false eons and the division of the mine of waste, he was nothing like nothing... The higher and more beautiful it would be if the people opened their own schools and madrasasahs, sent children to European dorilfunununlarig, doktur, advokat, editor and craftsman, traders and engineers (injiner), each of them stood in their duties, the order of the work and observe the benefit of our people!"he would indulge in dreams" (Steppe. Works: three volumes. C.2. The novel. Stories. Travelogue. Translations. - Tashkent: publishing house of literature and art, 1994. 472 p. - 271-280-page), such a role as the plot of the drama" Padarkush"," us rodent ills"," a'ymolimizyoinkimurodimiz " in the articlessuffering .The importance of articles such as" vices that bite us","a'molimizyoinkimurodimiz "or" begging or light profession " is shown by analyzing the national living situation in them. In Uzbek literature, there was no mention of the original situation in the life of people at that time and even before, about the vices of their Fe'l-at-Tirmidhi. Such works as" Padarkush"," Dokhtur Muhammad " brought literature closer to life and made people aware of their condition. The problems raised in" Padarkush"," us rodent vices"," begging or light profession "and"DokturMuhammadiyor" were not only related to the Turkestan country. Social life at that time was the same in almost all countries of the world. Poverty, poverty, especially the colonial countries had its own vortex. Some states in the West, based on colonialism,violence, were pegged in the development chapter, while the Eastern countries were degraded in all respects. In this region, the local population was immersed in the swamp of ignorance, superstition, because of the infallibility of enlightenment.While explaining the Congress events of Mahandi Gandhi (1869 - 1948)in 1901 year: "Tamil delegates felt themselves insulted from a onetime drop in the eyes of foreign people when they lay down to eat" (Gandhi M.K. My life. Tashkent: "new generation of the century", 2016-336 p. - 154-page) can be proof of this. It became common for the strong to crush the 
weak from himself, insult and humiliate him. Therefore, at the beginning of the XX century for the literature of all the peoples of the world, it was the main topic of showing this state of life. When people moved away from enlightenment and plunged into the swamp of ignorance, they could not notice that all men were servants of God, regardless of race, religion, nationality, social status, rich or poor. Many people, especially officials, had forgotten that neglecting a rich man, ignoring his Creator, insulting a man, humiliating, humiliating the world in the sentence was to do evil. Worry the person that mankind has not yet been able to get rid of this evil, which has been suffering since time immemorial. Because, reading, writing, although it is well known to use modern technical equipment, most people now do not even look at others, do not understand their own selfishness, conscience, do not realize their own self-esteem, do not forget about their own happiness. Therefore, even now, oppression and violence reign in life.It takes power from such negative feelings as selfishness, self-interest, vanity, self-interest in the hearts of the same illiterate people who turn life into darkness. The injustice of the present and previous times, the dignity of Man, the subjugation of his rights, arises from the fact that people do not feel that he is a servant of all God, oppression of Man, violence does not please his Creator. To look at people with indifference, to suffer oppression darkens their hearts, narrows their worldview and causes a sad situation in all respects. Makhatma Gandhi, who lived in a time when it was written" Padarkush"," begging or light profession"," DohturMuhammadiyor", an example of a living situation in this regard: "it is clear that sweets are shared. As long as the poor people of Ahmadabad came here as guras-guras. That's as long as the punches that these hungry people started after the sweetness caused confusion and confusion. Poverty and hunger in our country are such that every year a new population of the population becomes poor. Fighting for bread by giving his soul to the tyrant is destroying every sense of decency and mutual respect in them. And the people of philanthropy, instead of providing people with a job that gives them bread, push them to charity" (the same source. 249-page). With the distribution of food, clothing-head, people's lives can not be made comfortable. Show kindness, generosity will give an interimtemporary effect in all time. This work is carried out with the intention of motivating to get out of a difficult, difficult situation. But this measure does not change the lifestyle of people at all.Therefore, in order for people to forgive, it is not necessary to give alms, but to create jobs for them so that they can live, find bread for themselves. When a person enjoys knowledge, he does not stand by someone's kindness, sympathy.From living in the garden, he himself will work. And labor grows a person's consciousness and becomes a man who builds it. Enjoyment of knowledge brings a spirit of creativity to the activity of a person and gives meaning to his life. The causes of the tragedy in the drama" Padarkush", the basis of the sad reality in the story" Dakhtur Muhammad", the sufferings of the author of the article" begging or light profession " are traced back to the infallibility of people from science and education. Padarkush, that is, the Stone that has become the murderer of his own father, is bored of the existing marriage, does not know where to spend his youthspecific strength, is attached to the hooligans of the poppies and given to the crazy. If Toshmurad was busy with reading, science,artistry, he was never bored when he tried to master a profession. He steps into the 
street of crime for the reason that he is bored without knowing how to spend his time.Makhmudhu'jaBehbudiy and his comrades indicate in their works that all dishonesty in marriage, neglect of Criminal people in science and education, as a result of which the worldview becomes narrow, arises from boredom. The author described the drama " Padarkush "by the persona intellectuals in it:" the consequence of Science and ill-educated children(ng) is shul. If only the father had taught these things, it would not have been a crime and a padercushlik, and these would not have made the diet indifferent right, without drinking alcohol alone. He would not have remained in hell for as long as his life and for the band and the doomsday. If these were not to drink, the world and the hereafter would not have suffered and labored forever. Oh, in truth, it is the illusion that he killed the rich and made the suffering of the young man forever. It is the immorality and ignorance that makes us bankrupt, bachagiryon and impoverished and bandied: impoverishment, impoverishment, complication,impoverishment and humiliation are all the fruits and results of ignorance and neutrality. The people who have developed into the world develop by means of science. Those who are captives and Conquerors-at beilliness. As long as we are ill-educated and do not teach our children, plenty of bad events and misfortunes should always reign between us. There is no other way than to read and read about the disappearance of these works" (Behbudy M. Selected works. - Tashkent: "Spirituality", 1997. - 232 p. Ends with the words-49-page). All know today that these words, full of grief, suffering, are in fact Mahmudkhu'jaBehbudiy and his comradesfaryodi, Nida. When the situation of the people reaches a deplorable level, the self- sacrificing people who live with the grief of the people and bravely raise the problems that are torturing everyone, struggle for the benefit of the country and pass through their personal lives will come out on the square. Mahmudkhu'jaBehbudiy became the leader, the leader of such courageous people who appeared on the stage of history with the permission of Allah. He drew attention to the actual problems of social life in a timely manner, having received the attention of elyurt with the indication of their solution, and because of his multifaceted and vibrant activity, he was perceived by advanced intellectuals of the time as his patron. His courageous speeches on the sad situation in our national life, the need to master knowledge in order to change the existing impoverished state, the need to reform the educational system at the level of modern requirements, the establishment of theaters, Since the Islamic religion, the author of the" vices that gnaw us", can serve as a basis for the development of states, for which it is necessary to get rid of superstition, fanaticism, to live a comfortable life not only of Turkestan, but also of all peoples, to express sympathy and understanding for the benefit of Muslims, without affecting other religions, their contemporaries gained In particular, in the "travel memories":"as we, the turkistans spent the wedding, the dead and the polygamous, these Muslim relatives ( lazgin, dog'istani, chechen, Kom and other Muslims in the Caucasus) took their property to the girl, fled to janzholik, killed each other, killed several of the tarasins again in the name of qasu, and then got their money sudusinod road and spent their lives in Siberia they would have died as spending in the steppes. In the name of madrasa among them there is not a thing (thing) suck. But they themselves are 


incredibly believers and impractical

Muslims!.."(That source. - 60-page) wrote.

\section{REFERENCES}

1. Behbudiy M. Selected works. - Tashkent: "Spirituality", 1997. - 232 p.

2. Gandhi M.K. My life. - Tashkent: "new generation of the century", 2016-336 p.

3. Fitret A. Selected works. Volume 1: poems, prose works, dramas. - Tashkent: "Spirituality", 2000. - 256 b.

4. The steppe. Works: three volumes. C.2. The novel.

Stories.Travelogue.Translations.

Tashkent: publishing house of literature and art, 1994. - $472 \mathrm{p}$.

5. The steppe. Works: four volumes. Volume 1: poems, cults, poetic letters. - Tashkent: "Akademnashr", 2013. - 384p.

6. National Encyclopedia of Uzbekistan. 9volume. - Tashkent: State Scientific Publishing House" National Encyclopedia of Uzbekistan", 2005 -704 p.

7. Kadiriy A. Small works. - Tashkent: publishing house of artistic Literature named after GafurGulom, 1969. - 216 p.

8. Kadiriy A. Past days: historical novel. Tashkent: publishing house of literature and art, 1974. - $400 \mathrm{p}$.

9. Kadiriy A. DiyoriBakr: poems, stories, stage works, hangoma, fel'eton and articles. - Tashkent: "new generation of the century", 2007. - $472 \mathrm{p}$. 